HEKINIAN R., CHAIGNEAU M. and CHEMINEE J . L . (1973)

(Reprinted from Nature, Vol. 245, No. 5425, pp. 371-373, October 19, 1973)

\section{Popping Rocks and Lava Tubes from the Mid-Atlantic Rift Valley at $36^{\circ} \mathrm{N}$}

- During the 1972 Midlante* cruise of the RV Jean Charcot to survey a limited area of the rift valley south of the Azores, a dredge (CH-DR11) was taken at a depth of 1,360 fathoms in a depression near the foot of the eastern wall at latitude $36^{\circ} 49.3^{\prime} \mathrm{N}$ and longitude $33^{\circ} 15^{\prime} \mathrm{W}$. Two types of rocks were recognized from their structure and their degree of weathering. One type is "slab-like" rock, 2 to $13 \mathrm{~cm}$ in diameter and 1 to 2 $\mathrm{cm}$ thick (Fig. $1 a$ and $b$ ). The other type of rock consists of oval glassy pebbles $(1$ to $5 \mathrm{~cm}$ in diameter, Fig. 1c) which were observed to jump and explode, one or two at a time, for $3 \mathrm{~d}$ after the dredge haul was emptied on to the deck of the ship.

Here we report two volcanic phenomena which have been only rarely described in the literature from first hand experience, namely, the occurrence of lava tubes in the ocean and the observance of "popping rocks". To our knowledge, popping rocks have only been reported twice before; once from the southern part of the continental slope west of Baja, Caljfornia, by Krause' and once from the Confederation Peak area at $45^{\circ} \mathrm{N}$ on the Mid-Atlantic Ridge by Aumento ${ }^{2}$.

The lava slabs are slightly concave on one side, with a thin film of manganese and iron oxide coating, whereas the convex side is rugose and sometimes shows wrinkles indicating the direction of lava flow (Fig, $1 b$ ). The convex surface consists of a palagonite crust with small amounts of fresh glass (Fig. 1a) Both surfaces of the slabs are weathered but the inner portion is fresh (Fig. $1 b$ ). The slabs are primarily made up of basaltic glass which becomes more crystalline towards the concave side. The most crystalline portion of the slabs has tiny, poorly crystallized laths of what is probably plagioclase and traces of small euhedral olivine. Centres of crystallization with polygonal outlines rimed with glassy veins have also developed

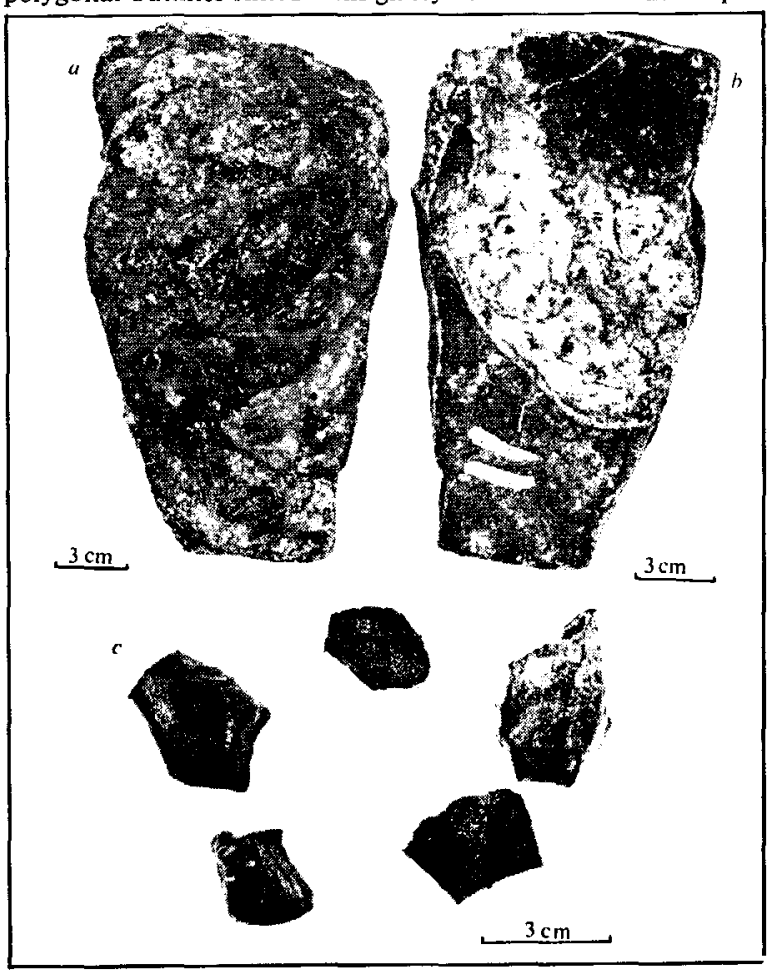

Fig. $1 a$, Convex surface of a slab fragment showing glass zones (dark), palagonite, and a thin film of manganese; $b$ concave side of a slab fragment showing thin ridges, manyanese coating (dark area), sediment (light area) and traces of organisms (dark streaks); $c$, angular fragments of "popping rocks"; some show a concave breakage surface.

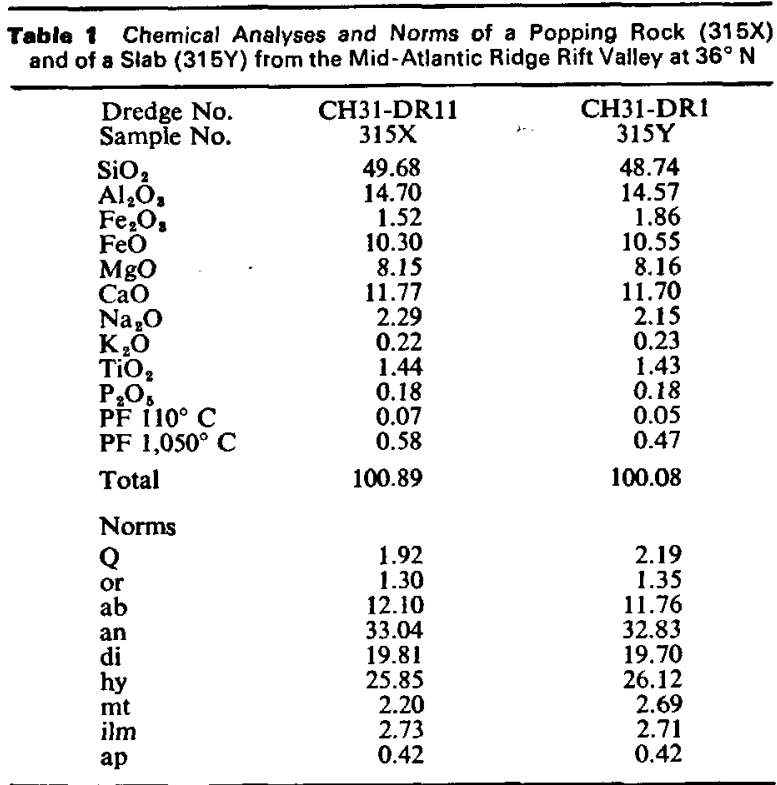

PF ignition.

Analyst: P. Cambon.

in the less glassy portion of the rock. We think that these slabs are fragments of lava tubes which have collapsed after drainage. The side of the arched surface shows the occasional occurrence of small ridges which are $3 \mathrm{~mm}$ high and $3 \mathrm{~mm}$ thick. A similar structural feature has been found on the internal walls of lava tunnels from Mount St Helens in Washington and was attributed to the remains of lava which solidified along the walls during drainage

The exploding rocks found in the same dredge as the lava tubes jumped approximately 50 to $100 \mathrm{~cm}$ while making a loud noise similar to that of popping corn. Each pebble shattered into at least two pieces having a chonchoïdal fracture and concave breakage planes (Fig. $1 \mathrm{c}$ ). The rock fragments are black and glassy and contain occasional skeletal olivine $(<0.07 \mathrm{~mm}$ in length). A grill-like network of what seems to be incipient plagioclase needles abounds throughout. Vesicles less than $1 \mathrm{~mm}$ in diameter comprise about $3 \%$ of the bulk rock.

Table 2 Volume Percentage of Gases of the Popping Rock (DR1 1 $315 X)$ and of a Glassy Margin of a Pillow-lava Fragment from the Rift Valley at $36^{\circ} \mathrm{N}$

\begin{tabular}{ccc}
\hline Volume $\%$ & DR11-315X & DR1-112 \\
$\mathrm{HCl}$ & 6.6 & 6.5 \\
$\mathrm{CO}_{2}$ & 38.8 & 44.0 \\
$\mathrm{CO}^{2}$ & 16.8 & 12.6 \\
$\mathrm{SO}_{3}$ & 10.3 & 1.7 \\
$\mathrm{H}_{2} \mathrm{~S}$ & 0.2 & None \\
$\mathrm{CS}_{2}$ & None & Trace \\
$\mathrm{H}_{2}$ & 26.7 & 34.7 \\
Methane & 0.2 & 0.2 \\
Ethane & Trace & Trace \\
Propane & 0.2 & Trace \\
Butane & Trace & Trace \\
Ethylene & Trace & Trace \\
Propylene & Trace & Trace \\
Butene & Trace & Trace \\
$\mathrm{C}_{6} \mathrm{H}_{6}$ & Trace & Trace \\
Helium & None & None \\
$\mathrm{N}_{2}+\mathrm{Ar}$ & 0.1 & 0.2 \\
\hline
\end{tabular}

Sample DR 1-112, located at $36^{\circ} 45.65^{\prime} \mathrm{N}$ and $33^{\circ} 16.55^{\prime} \mathrm{W}(1,337$ 1,408 fathoms) is a tholeiite with a few olivine crystals and with less than $10 \%$ vesicles $(<1 \mathrm{~mm}$ in diameter $)$. The $\mathrm{HCl}$ in the released gases was determined separately, using silver phosphate as a reagent and measuring the amount of silver chloride formed. 
The chemistry of a popping rock (sample $315 \mathrm{X}$ ) and of a lava tube (sample $315 \mathrm{Y}$ ) Is shown in Table 1 . The analysis of the lava tube was made on the fresh interior of the slab. Both types of rocks are low alumina tholeiites which are oversaturated with respect to silica. These rocks have a similar composition to other Mid-Atlantic ridge basalts, ${ }^{2,-4}$. Ignition $\left(\mathrm{H}_{2} \mathrm{O}+\mathrm{CO}_{2}\right)$ gave values less than $0.7 \%$ for both types of rocks (Table 1). After heating the samples to $110^{\circ} \mathrm{C}$ only minor amounts of volatiles $(0.06 \%)$ escaped. Most of the volatiles escaped when heating the sample to $1.050^{\circ} \mathrm{C}$. This suggests that most of the volatile content was concentrated within the glass and represents the original amount of volatiles present in the lava during extrusion.

Unfortunately we did not have to hand an appropriate container in which to bring back some of the popping rocks before they exploded; the amount and types of gases released during the explosions are thus not precisely known. A laboratory study of an exploded popping rock reveals the presence of various gases and the results of the mass spectrometry study are shown in Table 2 . In order to compare the gas content of the popping rock with that of another oceanic basalt which did not explode on the ship's deck, analyses of gases were also done on some fresh glass representing the chilled margin of a tholeitic pillow-lava fragment (DRI-112) dredged from the same general area of the Mid-Atlantic Rift Valley (Table 2).

To extract gases from the two samples, $10 \mathrm{~g}$ of fragments varying in weight from 0.3 to $0.6 \mathrm{~g}$ were first gradually heated in a vacuum to a temperature of $1,000 \mathrm{C}$ and then ground into a fine powder $(\therefore 0.125 \mathrm{~mm}$ in diameter $) ; 10 \mathrm{~g}$ of the powder was again gradually heated in a vacuum to $1,000^{\circ} \mathrm{C}$ to release still more gases from the glassy network. Observations made during the discharge of the gases are shown in Table 3. Small explosions were noted in both samples although the popping rock had a larger temperature range $\left(180\right.$ to $400^{\circ} \mathrm{C}$ ) than did the glassy margin of the pillow lava $\left(400\right.$ to $450^{\circ} \mathrm{C}$ ) (Table 3 ). The total volume of gases evolved from the popping rock (DR11-315X) is higher $\left(0.881 \mathrm{ml} \mathrm{g}^{-1}\right.$ ) than the volume released from the glassy margin of the pillow lava $\left(0.734 \mathrm{ml} \mathrm{g}^{-1}\right)$ (Table 3). The volume of gas evolved from both tholeiitic glasses is four times greater than the gas content of a continental obsidian from Lipari which released only $0.281 \mathrm{ml} \mathrm{g}^{-1}$ (ref. 7).

The volume percentage of gases released from the two samples is shown in Table 2. Traces of hydrocarbons were observed in both samples. The chief differences noted between the two samples are in their $\mathrm{SO}_{2}, \mathrm{CO}, \mathrm{CO}_{2}$ and, to a lesser extent, their $\mathrm{H}_{2}$ contents. The popping rock has a considerably higher $\mathrm{SO}_{2}$ content $(10.3 \%)$, a higner $\mathrm{CO}$ content $(16.8 \%)$, and a lower $\mathrm{H}_{2}(26.7 \%)$ and $\mathrm{CO}_{2}(38.8 \%)$ content than does the glassy margin of the pillow lava fragment. Interestingly, there was no smell of sulphur as the popping rocks exploded during $3 \mathrm{~d}$ on the ship's deck. The lower $\mathrm{H}_{2}$ and $\mathrm{CO}_{2}$ contents observed in the laboratory comparison of the popping rock and the glassy margin of the pillow lava may indicate, however, that the $\mathrm{CO}_{2}$ and $\mathrm{H}_{2}$ were responsible for the explosion of the popping rocks on the ship.

This latter consideration is valid if we assume that the original gas contents of both the popping rocks and the glassy margin of the pillow lava, on solidification, were initially the same. The popping rocks expioded when gases were released along lines of weakness near the surfaces of the fragments. This release of gas was probably a result of the sudden change in pressure and temperature when the rocks wiere brought to sea level. We believe, however, that the change of ambient pressure

Table 3 Laboratory Observations During Degassing Procedure on Two Rift Valley Samples from $36^{\circ} \mathrm{N}$ in the Atlantic Ocean

\begin{tabular}{|c|c|c|c|c|}
\hline \multirow{3}{*}{$\begin{array}{l}\text { Temperature at } \\
\text { the beginning of } \\
\text { gas release }\left({ }^{\circ} \mathrm{C}\right)\end{array}$} & \multicolumn{2}{|c|}{ DR $11-315 X$} & \multicolumn{2}{|c|}{ DR $1-112$} \\
\hline & $\begin{array}{l}\text { Coarse } \\
\text { fraction }\end{array}$ & Powder & $\begin{array}{l}\text { Coarse } \\
\text { fraction }\end{array}$ & Powder \\
\hline & 217 to 220 & $255 \pm 5$ & $260 \pm 5$ & $265 \pm 5$ \\
\hline $\begin{array}{l}\text { Volume of gas } \\
\text { released at } 0^{\circ} \mathrm{C} \\
\text { and } 760 \mathrm{~mm} \mathrm{Hg}\end{array}$ & $\begin{array}{l}0.672 \\
\mathrm{ml} \mathrm{g}^{-1}\end{array}$ & $\begin{array}{c}0.209 \\
\mathrm{ml} \mathrm{g}^{-1}\end{array}$ & $\begin{array}{l}0.587 \\
\mathrm{ml} \mathrm{g} \mathrm{g}^{-1}\end{array}$ & $\begin{array}{c}0.14 \\
\mathrm{ml} \mathrm{g}^{-1}\end{array}$ \\
\hline Weight loss (\%) & 0.56 & 0.09 & 0.45 & 0.08 \\
\hline $\begin{array}{l}\text { Approximate } \\
\text { temperature range } \\
\text { of explosion }\left({ }^{\circ} \mathrm{C}\right)\end{array}$ & 180 to 400 & None & 400 to 450 & None \\
\hline
\end{tabular}

during the emplacement of the lava flow on the floor of the Rift ( 250 to 300 bar) to that of sea level (1 bar) is the most important factor governing the explosions observed on deck. The explosive nature of these glassy basalts suggests an extremely recent extrusion of lava and it seems, in fact, that the lava flow had not yet had time to come to equilibrium with the pressure and temperature conditions of the rift floor. The presence of only a few skeletal olivine crystals indicates that the quenching temperature of the lava was near to that of olivine crystallization which is greater than $1,100^{\circ} \mathrm{C}$ at 250 to 300 bar.

We thank Captain Priser, the chief scientist V. Renard, the crew and the scientific party participating in this cruise of the RV Jean Charcot.

Centre Océanologique de Bretagne, BP 337, 29273 Brest

\section{R. HeKinian}

Centre National de la Recherche Scientifique,

Service d'Analyse des Gaz,

4 Avenue de lObservatoire,

75270 Paris 75006

M. Chaigneau

Centre National de la Recherche Scientifiaue, Geol. Dyn., 4 Place Jussieu.

75230 Paris Cédex 05

Received July 13, 1973.

${ }^{1}$ Krause, D. C., thesis, Univ. California, San Diego (1962).

'Aumento, F., Can.J. Earth Sci.. 5, 1 (1968).

${ }^{3}$ Greeley, R., and Hyde, J. H., Geol. Soc. Am. Bull. 83, 2397 (1972). Muir, I. D., Tilley, C. E., and Scoon. J. H., J. Petrol., 7 (2), 193 (1966).

- Miyashiro, A., Shido, F., and Ewing, M., Contrib. Minorel Petrol., 23 (2), $117(1969)$.

- Hekinian, R., and Aumento, F., Mar. Geol., 14, 47 (1973).

'Chaigneau, M., and Bordet, P., C.r. hebd. Séanc. Acad. Sci. Paris, 255, 3019 (1962).

* Mid-Atlantic Ridge survey part of the Franco-American MidOcean Undersea Study (Famous) program. 